\title{
Introducing the religio-centric positional advantage to Indonesian small businesses
}

\author{
Hendar HENDAR \\ Universitas Diponegoro (UNDIP) and Sultan Agung Islamic University, Semarang, \\ Indonesia \\ hendar010263@yahoo.com
}

Augusti Tae FERDINAND

Universitas Diponegoro (UNDIP), Semarang, Indonesia

Tatiek NURHAYATI

Sultan Agung Islamic University, Semarang, Indonesia

\begin{abstract}
With a focus on small religion-based businesses in Indonesia, this research examines whether marketing innovativeness, customers responsiveness and competitors' responsiveness can improve marketing performance. A conceptual model on the correlation of these three variables with religio-centric positional advantage and marketing performance is examined by using structural equation model. For this purpose 335 small businesses of Islamic Fashion had been studied using purposive sampling from 11 regencies/cities in Central Java (Indonesia). The results showed that (1) small companies in these market segments based on religion is likely to have better marketing performance when they have the Religio-centric positional advantage, (2) The increase in marketing innovativeness, CuR and CoR is required to improve and maintain religio-centric positional advantage, and (3) religio-centric positional advantage is definitely a mediator in the correlation of marketing innovativeness, customer responsiveness and competitors responsiveness with marketing performance.
\end{abstract}

Keywords: marketing innovativeness, customer responsiveness, competitor responsiveness, religio-centric positional advantage, marketing performance.

Please cite the article as follows: Hendar, H., Ferdinand, A.T. and Nurhayati, T. (2017), "Introducing the religio-centric positional advantage to Indonesian small businesses", Management \& Marketing. Challenges for the Knowledge Society, Vol. 12, No. 1, pp. 78-102. DOI: 10.1515/mmcks-2017-0006.

\section{Introduction}

The Indonesian Islamic fashion market has attracted the attention of both domestic and foreign businesses seeking to expand their horizons and to gain a deeper understanding of Muslim customers. Indonesia's cultural diversity is the result of a complicated history, and most of this complexity arises from the historical relationship between Indonesia and Islam, Indonesia and Western societies and the intellectual history of women. Therefore, Muslim fashion is a part of culture that arises because of the complex mixing of Indonesia, Islam, the West and the intellect (Gökariksel and McLarney, 2010). This complexity can be transformed into a business opportunity and this encourages more and more businesses to enter the Indonesian Muslim fashion market.

Popular culture plays a great role in shaping fashion trends, and fashion companies' performance is determined by their ability to quickly respond to changes in fashion trends and transform these trends into products available in stores in the shortest time possible (Barnes and Lea-Greenwood, 2006, 2010). Commonly, the fashion 
industry is based on products or markets with style elements that tend to persist only for a short period (Christopher et al., 2004), and in the Muslim fashion industry, designs are very easily imitated, meaning that production lasts only for successful items (Barnes et al., 2006; Barnes and Lea-Greenwood, 2006). Within the scope of such a market, companies need three types of capabilities, namely adaptive capability, absorptive capability and innovative capability (Wang and Ahmed, 2007; Barnes and Lea-Greenwood, 2010).

The adaptive capability is needed to identify and take advantage of growing market opportunities (Milles et al., 1978), which means that it reflects the company's ability to respond to new market conditions (customers and competitors). The absorptive capability is the company's ability to acquire new value from external information, assimilate, and apply it in the form of commercialization (Wang and Ahmed, 2007) and the innovative capability is the ability to develop new products, new processes, new organizations and new markets by adopting an innovative orientation (Alpay et al., 2012). The innovative capability is reflected in the tendency for companies to engage and support new ideas, novelty, experimentation, and creative processes that can produce new products, services, processes or technologies (Lumpkin and Dess, 1996). Marketing innovativeness (MI) is the activity involved in the implementation of three core business processes, i.e. the management of product development, supply chain, and customer relationship (Srivastava et al., 2001; Cascio, 2011). This study focuses on the role of adaptive capability (responsiveness to customers and competitors) and innovative capabilities (MI) in gaining positional advantage and improving marketing performance in religion-based market segmentation.

The study of MI and its impact on the company's performance has become an important concern for researchers and business practitioners (Moreira et al., 2012). Some studies have found that MI plays a significant role in improving marketing performance, while several other researchers found the opposite. Changes in product strategy, pricing, promotion, channel, and customer relationships are important parts of MI and represent fundamental elements of all strategies for achieving market success (Moreira et al., 2012). MI in the form of full support to research activities and market development, technology leadership and innovation, the multiplication of product lines, as well as creativity in product strategy, pricing, distribution channels and promotion is an important trigger for increased marketing performance (Al-Saed et al., 2010; AlZyadaat et al., 2012; Karabulut, 2015).

Nevertheless, some studies have found that MI is not a direct predictor of improved marketing performance. For example, product innovativeness is not a determinant of new product marketing performance (Yalcinkaya et al., 2007; Tsai and Hsu, 2013), radical marketing innovation does not affect marketing performance (Shergill and Nargundkar, 2005), MI is not an important driver of marketing performance improvement (Atalaya et al., 2013), and an increase in the innovation market does not have a positive impact on the performance of the company (Rosli and Sidek, 2013).

The implications are that even though theoretically MI is a strategic way to improve marketing performance, practically, MI does not always produce better marketing performance. For that matter, some studies have suggested that in order to produce better marketing performance, MI should result in competitive advantage or positional advantage in advance (Morgan, 2012; Ahmadi et al., 2013). For those companies which use religion as the basis market segmentation and targeting, focusing on meeting customer needs for products that support their commitment to their 
religious values and beliefs, building bonds with targeted customers, providing the best service to customers and branding the company with values of religiosity represent valuable opportunities for achieving positional advantage and improve marketing performance. In other words, MI which enables the company to gain religio-centric positional advantage (RPA) represents a great opportunity to improve marketing performance.

In this study, MI is not the only determinant of RPA and small business marketing performance, as we have other antecedents of market responsiveness (customers and competitors) as the dominant drivers. The market responsiveness approach is often used to predict the marketing performance of small businesses. Based on customer surveys, some research findings have shown that a cultural orientation responsive to the market (customers and competitors) plays a major role in improving the company's performance (Carbonell and Escudero, 2010; Chao and Spillan, 2010; Chung, 2012). However, businesses with good market response capabilities are not guaranteed to have better abilities to improve their marketing performance than other businesses. Several other empirical findings demonstrate that the company's ability to respond to the market does not always have a positive impact on the company's performance (Johnson et al., 2009; Matanda and Ndubisi, 2009; Bodlaj, 2010; Dong et al., 2013). For that matter, some studies have suggested the importance of positional advantage as a mediator in the influence of market response capabilities on marketing performance (Langerak et al., 2004; Nakata et al., 2006; Adis and Jublee, 2010). If this insight is applied to the industry producing products that are closely related to religious cultural phenomena such as Muslim fashion, it is possible for the positional advantage based on religion to mediate the relation of market response capability and the company's marketing performance.

\section{Conceptual development}

\section{Religio-centric positional advantage (RPA)}

Positional advantage is a concept derived from the approach of resource advantage theory (RA-Theory). According to Hunt and Morgan (1995), RA-Theory is a general theory of competition which explains that the fundamental objective of the strategy based on resources is to achieve resource-based comparative advantages which can generate a positional advantage in several market segments in order to obtain superior corporate performance. Resources and marketing capabilities determine the quality of decisions and the implementation of the corporate marketing strategy. Furthermore, the quality of the marketing strategy will determine the company's positional advantage, and that advantage will determine both marketing and financial performance (Morgan, 2012). The positional advantage discussed here is the relative value of the results of a marketing strategy that is delivered to the target market to the alternatives available to the customer. The positional advantages described are in terms of product features, service, price, cost, image and positional advantage based delivery (Morgan, 2012). This study focuses on the positional advantage based on image, i.e., the image of religious companies that still get less attention from researchers.

The religio-centric concept is derived from the social identity theory. This approach highlights the importance of ethnocentrism as one of the cultural elements that is mostly studied to reveal its impact on customer choice (Kaynak and Eksi, 2011; Lee et al., 2013). Ethnocentrism relates to a combination of a positive attitude towards members of the same ethnic group and a negative attitude towards members outside of the same ethnic group (Kaynak and Eksi, 2011; Lee et al., 2013; Jiménez-Guerrero et al., 
2014). Ethnocentric customers tend to evaluate positively the products which belong to their own group and negatively the products that are not. Ethnocentric customers will tend to reject people, symbols and values of different cultures because their cultural objects are their pride (Herche, 1994). The ethnocentric behavior based on group boundaries is usually defined by one or more of observable characteristics such as religion.

From the perspective of social identity and ethnocentrism, religio-centrism is inherent in religion because it establishes the identity of both individuals and groups. Religio-centrism is, thus, a part of ethnocentrism. Religio-centrism implies a combination of a positive attitude towards members of the same religious group and a negative attitude towards members of other religious groups (Sterkens and Anthony, 2008). Religio-centrism reflects the religious sentiment that an individual seeking the fulfillment of personal interests should act based exclusively on the teaching of his religion (Ray, 1972). Faithful individuals, who are religio-centric, deny the truth of other religions and hold the absolute truth of their religion, and will not give space to the different religious practices (Abu-Nimer, 2004). Members of religious groups which are affiliated to a particular religion will consider the attributes of religiosity of their religion better than the attributes possessed by other religious groups (Sterkens and Anthony, 2008).

The synthesis of positional advantage and religio-centrism leads to the construction of a new concept of religio-centric positional advantage. This concept is defined as the superiority of the religious value that is embedded in the corporate image, aesthetic design, fashion model religiosity, adherence to religious norms and display marketing communications designed to increase customer value. The company's image is an important criterion of positional advantage (Matear et al., 2004; Morgan, 2012). The aesthetic value in Muslim fashion is an element of culture that imprints its own image on the personality of the individual. Positional advantages can be designed by placing elegance or beauty of product design (Forney et al., 2005).

In some studies, positional advantage is described as a result of excellence in merchandise fashionability (Bridson et al., 2013), style (appearance) following the trend, creating fashionable designs and following fashion trends (Roy and Goswami, 2007). In market segments based on religion, positional advantage can be designed by offering fashionable religious products that follows the development mode. In addition, other studies have used other indicators of positional advantage such as comfort (Morgan, 2012), ability to solve customer problems (Langerak et al., 2004), technical performance, attractive designs and attributes or features (Healy et al., 2014), or the uniqueness of the benefits offered to (Yang et al., 2014). Given that religiosity affects the feelings and attitudes towards consumption (Hanzaee and Chitsaz, 2011; Saida et al., 2014), then the product should allow the customer to comfortably follow the norms of religion, it should be able to solve customer problems related to the needs of religiosity, to meet customer needs in regards to religious activities, and it should have a technical performance that supports religious activities, and features and design in accordance with the norms of religion concerned.

Image positioning is the foundation for communicating messages to targeted customers. Marketing communication channels, such as advertising, direct marketing, sales promotion, sponsorship, publicity, public relations, Internet, and communications integrated corporate image, can be used to communicate the position of the company's image in the minds of the target customers. Several studies have described the positional advantages as excess in communication with customers (Brïdson and Evans, 
2004), superior reputation for quality, excellence corporate image, more attractive product packaging (Carbonell and Rodriguez, 2006; Morgan, 2012), personal selling (Bridson et al., 2013), and excellence in service, superiority of the company's image (Brïdson and Evans, 2004; Morgan, 2012; Irsic, 2014). For market segments based on religion, the corporate image needs to be displayed by using the symbols of religiosity in accordance with the norms of a particular religion.

\section{Marketing innovativeness (MI)}

Marketing innovation is defined as the ability to implement a concept or a new marketing strategy which is different from the common marketing methods used by the company, including changes in the design or in product packaging, distribution, promotion and price of a product that is intended to increase the market penetration of goods, services and increase sales (Moreira et al., 2012; Karabulut, 2015). Marketing innovation is described using three dimensions, namely innovation in the product, associated with changes in the physical product; innovation in the service, associated with changes in the customer service process by utilizing available resources effectively and efficiently; and innovation in delivery rate including changes in the logistics and channels used to deliver the product to the buyer (Kim and Mauborgne, 1997). Thus, marketing innovation is basically explained by the marketing space of product, processes and relationship (Cascio, 2011).

In the marketing-product space, marketing innovation is associated with the creative activity implicated in the creation of new products and services or in the increase of the value of products and services that already exist. In this space, marketing innovation is done through creativity in understanding the needs of new customers, attracting new customers, designing a product solution, managing the functional units (departments), developing external networks, and coordinating the activities of product design efficiently. In the marketing-process space, marketing innovation is associated with creative efforts to convey the values of the organization or customer value efficiently and effectively in the order fulfillment process, including creativity in the management of suppliers and logistics, implementing workflow and manufacturing, managing channel distribution, and facilitating the use of the product. Moreover, in marketing-relationship space, marketing innovation is related to the creativity of the company reflected in its ability to attract and retain customers with the products and services currently available. In this space, innovation is done through creativity in determining the need for new products, new customers, advertising and promotion strategies, manage service and customer loyalty, and realize sales programs.

Innovativeness is an organization's culture, values and beliefs reflected in the exploitation of new ideas and the design of unique ways to produce new creations that significantly improve the quality of products, processes or services (Wong, 2012). Therefore, MI is the ability of a company to use the resources it possess in order to look for new marketing ideas, improve product design that is easily accepted by the market, to improve the position of their products in the minds of customers, to improve product promotion activities to make them readily accepted, to adjust product prices, to encourage its staff to generate new marketing ideas and to take the decision to implement new marketing ideas based on calculated risks (Naidoo, 2010). Srivastava et al. (1999) describe MI as a new level in the implementation of business process management, product development, supply chain management, and customer relationship management. MI is reflected in the behavior or tendencies of the entrepreneur to generate new products and services, new distribution methods and new 
sales, new designs or packaging for products or services, to improve the business processes that support the exchange of information, knowledge and skills within the company, as well as to improve organizational behavior within the company (Junge et al., 2015).

\section{Customer responsiveness (CuR)}

In general, companies which are highly responsive to customers are characterized by their efforts to pay attention and find solutions to customer problems, to build relationships with customers, to pay attention to customization of their offerings, to have a formal program to regularly meet customers to determine the needs of their service and to ask customers to provide feedback on practices and policies set by the company, and to have a formal internal process to check the level of quality service (Jaworski and Kohli, 1993; Daugherty et al., 1995; Jaworski et al., 2000; Pehrsson, 2014).

CuR is associated with the activities to provide added value for customers such as the adaptation of the product or service, solutions for customer problems, and building the relationship with the customer (Pehrsson, 2011). According to Chavosha et al. (2011), CuR is to provide customers with solutions to their legitimate needs in a timely manner. Therefore, CuR is the company's ability to respond to customer requests and adapt appropriately and quickly to obtain or maintain its competitive advantage in the marketplace. In order to enhance such capabilities, the company needs to continue to monitor, collect, analyze and distribute information about the changing needs and desires of existing or potential customers and have the speed necessary to generate new products that fit those changing needs.

In the fashion industry, the company's ability to respond quickly and appropriately to changing customer needs will focus on product design, motif variation product, the type and quality of the raw materials used, and the product model as the best way to get better business performance. This happens because the temporal patterns of adoption in the community shape fashion that shows the growth and setback phase. In the beginning, a certain style is introduced by a small group of fashion leaders. After this, many imitators scramble to enter this brief relative market. Soon, people get bored with the available products and customers will begin to adopt new behaviors and to look for an alternative style (Corneo and Jeanne, 1999). According to Fuentes and Quiroga (2009), fashion is a widespread social phenomenon and cannot be avoided from modern life, and changes in the appeal of fashion attributes will continue to influence consumption behavior of fashion customers. Therefore, the company's ability to offer a product with attributes that match the customer wants and needs is an entry point towards the success of business fashion. The product attribute here is anything attached to a product, including benefits, product quality, product features, product design, branding, packaging, labels, colors, product service, and distribution (Kotler and Armstrong, 2000).

\section{Competitor responsiveness (CoR)}

CoR is the company ability to understand the strengths and weaknesses of competitors' strategies both in the short and long term (Lewrick et al., 2011). This is the ability to collect and integrate information about the products and strategies of competitors, to analyze information regarding potential competitors, to share and develop knowledge about the strengths and weaknesses of competitors in the present and the future. Chung (2012) argues that companies which have the capability to respond to competitors are those which have the speed to react when a rival company launches a program to target 
customers, to respond to significant changes in the pricing structure of competitors, to respond to significant changes in the business environment (e.g., regulatory, technological, economy), and to respond to any other competitive actions that threaten the company in the market.

According to Nwokah (2009), in order to achieve better marketing performance, companies should focus on customers and competitors. The focus on competitors is associated with the company's activities to determine and understand the industry, identify and understand the competition, understand the strengths and weaknesses of competitors, and anticipate the moves of competitors. Customers' interest in the products produced by competing companies will attract a company to react quickly if the competitor's product strategy results harm the company concerned. The reaction occurs usually by changing the attributes of the products offered such as product quality, product features, product design, branding, packaging, labels, colors, patterns, models, service products, and distribution. In the fashion industry, the company's ability to respond quickly and appropriately to changes in competitor strategies is reflected in changes in product design, variations motif product, the type and quality of the raw materials used, and models of the products offered, as well as sales promotion strategies which will provide the best way to get better business performance.

\section{Marketing performance (MP)}

According to Morgan (2012) and Gao (2010), marketing is a very dynamic process so that MP is a multidimensional process that involves adaptability, effectiveness and efficiency. Adaptability is associated with the organization's ability to respond to environmental changes. Effectiveness relates to the extent to which the organization's goals and objectives can be achieved. Efficiency is associated with the performance results ratio to the inputs needed to achieve it. Normatively, MP measurement involves an assessment of the marketing resources and capabilities as a source of excellence, the achievement of positional advantage, market performance and unit sales, market share, and financial performance (Gao, 2010). Other researchers explained MP as the ability of the company to achieve its objectives in regards to market share, sales growth, and increase in new customers and retaining existing customers (Merrilees et al., 2011; Prasertsang and Ussahawanitchakit, 2011). MP is also described as the company's ability to preserve current customers, attract new customers, increase market share, improve customer satisfaction, improve the standard of sales growth, and add standard net income to sales (Soliman, 2011). This study describes MP as a combination of the results of marketing activities perceived by the owner or manager of the company about achieving sales growth revenue, increasing sales volumes, attaining sales targets, customer growth and expansion of the area of marketing.

\section{Research methodology Hypotheses formulation Marketing innovativeness and religio-centric positional advantage}

The resource based view has placed resources and marketing capabilities at the base of the improvement of positional advantage and marketing performance (Morgan, 2012). One of the important determinants of resource capability on the company's success in a dynamic market environment is the innovation capabilities or innovativeness (Wang and Ahmed, 2007). Innovativeness is related to the entrepreneur's willingness to support creativity and experimentation in introducing new products or services, novelty, technology leadership and R\&D in developing new processes (Lumpkin and 
Dess, 1996). In the context of marketing, MI arises when entrepreneurs make changes in strategic market planning and its implementation, manage the brand, CRM and NPD, and implement strategies that are typical in the marketing mix. These changes will further enhance the positional advantage (Morgan, 2012). Thus, MI as indicated by improvements in marketing strategy and its implementation has a major role in determining positional advantage. The latest findings have shown that $\mathrm{MI}$ in the form of products innovativeness becomes the dominant driver of competitive advantage (Naidoo, 2010; Abou-Moghli et al., 2012) or product positional advantage (Wong, 2012; Huang and Tsai, 2014).

In religious-based market segments, the company will target the religious customer group which is ready to be served, will build its positioning using religious values and provide the market with the right marketing mix strategy so that the religious value can actually be delivered to targeted customers. MI creativity in the form of right product strategy, pricing, distribution and promotion will allow the company to develop a positional advantage based on religious value and get a better marketing performance. In religious market segments, it will be easier to build RPA for companies with better MI reflected in the effectiveness of delivering value to customers' religiosity. For example, Halal products which are made in accordance with the guidance of Islam are the products that have the potential to have RPA and to be highly desirable for Muslim customers. Thus, the first hypothesis proposed is:

\section{H1: MI has a positive effect on RPA.}

\section{Customers responsiveness and religio-centric positional advantage}

Another marketing capability needed to gain a positional advantage and superior marketing performance is adaptive capability, which is the ability to respond to customers and competitors (Wang and Ahmed, 2007). This ability will enable companies to create and exploit external opportunities and develop excellence and durability when used with the insight and agility (Hitt et al., 2001). For example, a good ability to interact with customers is one of the most important marketing capabilities which enable companies to build closer customer relationships, and act as well as means to build a sustainable competitive advantage (Day, 1994). This means that responsiveness to customers is crucial for positional advantage in target market segments. The full mastery of customer information will enable the company to adapt to customer needs and requirements, to respond to the changing needs and desires of customers and, at the same time, to position the values of the product or the company in their minds. In the cultural context of market orientation, customer orientation and continuity of the company in the form of commitment in collecting information about customers (Narver and Slater, 1990) will allow the company improve positional advantage in target market segments (Hunt and Morgan, 1995). For companies that cater to specific market segments, such as companies that produce religious and serve religion-based market segments, customer commitment is very useful for building excellent RPA in the minds of customers. Therefore, the second hypothesis proposed is:

\section{H2: CuR has a positive effect on RPA.}

\section{Competitors responsiveness and religio-centric positional advantage}

Response capabilities toward competitors allows companies to reconfigure their processes to meet the needs of new markets, take advantage of information processing systems and adopt new products and processes to win the competition (Dong et al., 
2013). Therefore, it is not surprising that CoR is the key to improving competitive advantage. The ownership of superior resources represents the potential to generate competitive advantage and superior corporate performance (Hunt and Morgan, 1995). Resource capabilities such as CoR will enable companies to create and exploit external opportunities and develop excellence durability when used with the insight and agility (Hitt et al., 2001). Competitors-oriented companies have greater opportunities to gain a competitive advantage through differentiation and cost leadership (Zhou et al., 2009; Li and Zhou, 2010), and the superiority of their products (Langerak et al., 2004; Adis and Jublee, 2010). In a religious-based products market, the company's ability to be responsive to the competitive strategy will enable it to get product positional advantage. Thus, the third hypothesis proposed is:

\section{H3: CoR has a positive effect on RPA.}

\section{Marketing innovativeness and marketing performance}

Innovativeness is one of the company's ways to gain or maintain a competitive advantage and superior performance of the company. Dibrell et al. (2013) showed that product innovativeness is an important driver of competitive advantage and performance improvement of the company. Companies which have a tendency to get involved in finding ideas and supporting the discovery of new special products will have more possibilities to improve their performance. The ability of a company to develop and deploy a wide range of internal capabilities such as innovativeness and response capability is significant for the growth of small and medium enterprises (Sok et al., 2013). The increased MI in the form of creativity for companies to manage products, operating processes, market and creativity in designing business strategy will enable small and medium enterprises to get better performance (Ar and Baki, 2011; Alpay et al., 2012). The increased of MI in the form of corporate creativity in finding products, pricing strategy, managing distribution and promotion of new products will become a strong incentive to improve marketing performance (Al-Zyadaat et al., 2012). Thus, the fourth hypothesis proposed is:

\section{H4: MI has a positive effect on MP.}

\section{Customer responsiveness and marketing performance}

The correlation between the $\mathrm{CuR}$ and MP of the company can be referred to the initial view Narver and Slater (1990), which shows that the market orientation really becomes a strong driver for the improvement of company performance. The customer-oriented company is a company that is responsive to customers. Empirical findings indicate that companies which are responsive to their customers affect the performance (Carbonell and Escudero, 2010; Chao and Spillan, 2010; Rojas-Me'ndez and Rod, 2013), or the performance of the company's strategy (Chung, 2012). These findings indicate that the company's marketing performance improvement depends on CuR. In specific market based on religion such as Muslim fashion market, a company that has CuR has the potential to increase marketing performance. Therefore, the fifth hypothesis proposed is:

\section{H5: CuR has positive effect on MP.}




\section{Competitor responsiveness and marketing performance}

Knowledge of the strengths and weaknesses of competitors allows the company to identify and occupy the market position and profitable niche market (Day, 1994). In order to preserve a competitive advantage and to reach profitability, it is important for the company to carefully pay attention to movements of competitors and products on the market. A company with more complete information will be able to use the knowledge in a number of ways, including understanding the strengths and weaknesses of the competitors, internalizing competitors' strengths by imitation, or negating competitors' strengths by product differentiation. Narver and Slater (1990) explains that competitor orientation is an important determinant of superior financial performance on the long run. The competitor-oriented- company is a company that is responsive to competitors. Thus, the company's future success is largely determined by their capability in orienting competitors. Chao and Spillan (2010) found that the market response capabilities, both in response to customer and competitor affect the performance of the company. Carbonell and Escudero (2010), also found that the company's performance is significantly affected by the market's response capability (response to customers and competitors).

In a highly dynamic market environment, such as the fashion market, the competitive advantage may only be enjoyed in the short run, because the competitors will very likely and easily react on a strategy that produces excellence. The capability to react to existing competitors and potential competitors is required by companies that compete closely, not only to maintain a competitive advantage, but also to maintain or even increase performances. Thus, the company which has the ability to respond competitors will have the potential to improve marketing performance in the form of sales revenue, sales volume, sales territories, achievement of sales targets, and market share. Therefore, the sixth hypothesis proposed is:

\section{H6: CoR has positive effect on MP.}

\section{Religio-centric positional advantage and marketing performance}

Positional advantage has recently come to the attention of researchers since it is considered as a determinant of business performance (Langerak et al., 2004; O'Dwyer and Ledwith, 2009; Morgan, 2012). Researchers have confirmed that the achievement of the organization as reflected in a range of performance indicators is related to positional advantage (Morgan, 2012; Bridson et al., 2013). The positional advantage enjoyed by a company is seen as the excess over market share or profits in comparison to the competitors. The reason is that companies which offer greater value in products and services to their customers will generate better purchase-value than their competitors (Nakata et al., 2006). Therefore, the advantages which are attached to new products and new services outweigh those of the competitors. Researchers such as Cooper and Kleinschmidt (2000), Langerak et al. (2004), Nakata et al. (2006), Ledwith and O'Dwyer (2008) and Hsieh et al. (2008) have found evidence of the effect that the product advantages is one of the drivers of success of new product marketing. The previously shown conceptual and empirical evidence have consistently demonstrated the positional advantages as the most important characteristic in explaining the performance of a company's marketing.

This study examined whether the correlation of positional advantage and marketing performance is in line with the foundation of resource-based view literature and studies that are specific to small businesses based on religion (Morgan, 2012; 
Bridson et al., 2013). The positional advantage is captured by the competitive position of companies relative to their closest competitors in the number of small businesses in the Muslim fashion. Morgan (2012) describes that a positional advantage of companies can be obtained from a variety of dimensions, and they can be product excellence-based, service-based, price-based, cost-based, image-based, or delivery based. This study focuses on positional advantage of based image, the image of a religious enterprise. We consider that it is important to examine the effect of religious positional advantage or RPA on company image with marketing performance in specific market segments based on religion. Therefore, the seventh hypothesis proposed is:

H7: RPA has positive effect on MP.

\section{The mediating role of religio-centric positional advantage}

There are three important antecedents of positional advantages as described previously, namely MI, CuR and CoR. MI in the form of product innovation becomes the dominant driver in the increase of competitive advantage (Naidoo, 2010; Abou-Moghli et al., 2012; Wong, 2012; Huang and Tsai, 2014). CuR and CoR will enable companies to create and exploit external opportunities and develop excellence durability when used with insight and agility (Hitt et al., 2001). The response ability to customers and competitors is one of the factors that influence the strategic competitive advantage of the companies (Dong et al., 2013).Therefore, it is not surprising that the response capabilities of customers and competitors are of chief importance in improving positional advantage. Companies that have a positional advantage have a great potential in improving the performance of their business, including the marketing performance (O'Dwyer and Ledwith, 2009; Morgan, 2012; Bridson et al., 2013). In the religious-based market, companies that are innovative, responsive to customer needs and competitor strategies, will have a greater chance in getting RPA which will further have a positive impact on the marketing performance. Therefore, the hypotheses proposed are:

H8: RPA mediates the correlation between MI and MP.

H9: RPA mediates the correlation between MP and CUR.

\section{H10: RPA mediates the correlation between CoR and MP.}

\section{Sample characteristics and data collection}

The population in this study was formed by owners and managers of small Islamic fashion business in Indonesia having a maximum of 20 employees (Central Statistics Bureau, 2015). Considering that the characteristic of small businesses in fashion industries needs to be taken into account in order to develop an equal RPA measurement scale, the RPA scale and conceptual model explained in this study were examined using the data from small retail business, online retail, manufacture and wholesale. The samples were considered to have enough different with other three businesses because besides its number is more, their closeness to final consumers enables them to get initial information about consumers' desire. The data were obtained from distributing questionnaire to 427 respondents which were in 11 regencies/ cities in Central Java province. The questionnaire was delivered directly by the officers who were trained before to the owner of small business fashion or managers who are trusted to run the business. After 3 months of data collection, in fact, there were only 406 returned, or approximately $81.03 \%$. The final evaluation of the questionnaire received after being examined whether it was broken or it had outlier data, obtained 335 
questionnaires (78.45 \%) which could be used for data analysis. Snowball sampling technique was used to explore the position of prospective respondents of the research. The samples of small fashion business were selected using purposive sampling method with these criteria, (1) the respondents must have been minimally 3 years experienced because it was considered to have experience in business and know business performance development, and (2) did not have more than 20 employees. The selected respondents consisted of $76.7 \%$ females and $23.3 \%$ males aged between 25 years to 50 years old. Most of them were the owner and also the manager of small Islamic fashion business who were married and had more than 3 years of work experience. Table 1 summarizes the characteristic of each sample.

Table 1. The characteristics of the sample

\begin{tabular}{|c|c|c|c|c|}
\hline Sample size & $\begin{array}{l}\text { Retail } \\
(n=152)\end{array}$ & $\begin{array}{l}\text { Online Retail } \\
(n=54)\end{array}$ & $\begin{array}{l}\text { Manufacture } \\
(n=68)\end{array}$ & $\begin{array}{l}\text { Wholesale } \\
(n=61)\end{array}$ \\
\hline $\begin{array}{l}\text { Sex } \\
\text { Males } \\
\text { Females }\end{array}$ & $\begin{array}{c}26 \\
126\end{array}$ & $\begin{array}{c}8 \\
46\end{array}$ & $\begin{array}{l}25 \\
43\end{array}$ & $\begin{array}{l}19 \\
42\end{array}$ \\
\hline $\begin{array}{l}\text { Total of Employees } \\
1 \text { - } 5 \text { People } \\
6 \text { - } 20 \text { People }\end{array}$ & $\begin{array}{c}132 \\
20 \\
\end{array}$ & $\begin{array}{c}45 \\
9 \\
\end{array}$ & $\begin{array}{l}48 \\
20 \\
\end{array}$ & $\begin{array}{l}39 \\
22 \\
\end{array}$ \\
\hline $\begin{array}{l}\text { Position of Respondent } \\
\text { Owner } \\
\text { Manager } \\
\text { Owner and Manager }\end{array}$ & $\begin{array}{l}53 \\
25 \\
74\end{array}$ & $\begin{array}{l}23 \\
11 \\
20\end{array}$ & $\begin{array}{l}22 \\
10 \\
36\end{array}$ & $\begin{array}{l}20 \\
19 \\
22\end{array}$ \\
\hline $\begin{array}{l}\text { Business Experience } \\
1-5 \text { years } \\
6-10 \text { years } \\
11-15 \text { years } \\
\text { More than } 15 \text { years }\end{array}$ & $\begin{array}{l}64 \\
44 \\
14 \\
30\end{array}$ & $\begin{array}{c}35 \\
14 \\
2 \\
3 \\
\end{array}$ & $\begin{array}{l}28 \\
17 \\
12 \\
11\end{array}$ & $\begin{array}{c}23 \\
12 \\
5 \\
6 \\
\end{array}$ \\
\hline
\end{tabular}

\section{Models and validation}

The Structural Equation Model (SEM) was used to conduct the empirical study model using the data from the managers of small Islamic fashion businesses in Central Java, Indonesia. Confirmatory Factor Analysis Model was employed to measure the multidimensionality of a theoretical construct (construct validity test). Besides, SEM was also used as a comprehensive test instrument for full structural model. The data was analyzed under the process suggested by Hair et al. (2010).

This study reported the confirmatory factor analysis for the complete sample. The observation was conducted on 23 indicators ( $5 \mathrm{MI}, 5 \mathrm{CuR}, 4 \mathrm{CoR}, 5 \mathrm{RPA}$ and $4 \mathrm{MR}$ ) to obtain 23 scores of relevant factor loading $(\lambda 1-\lambda 23)$. The unidimensional assessment was conducted through estimating general least square standardized estimates factor loading, which was above 0,6 (Hair et al., 2010). Table 2 shows that the factor loadings of all observed latent variables had good validity because their scores were more than 0.6 being significant on $\alpha=0.01$. 
Table 2. Confirmatory factor analysis results for the measurement modela

\begin{tabular}{|c|c|c|}
\hline Marketing Innovativeness (MI) & $\lambda$ & $\begin{array}{l}\mathrm{p}- \\
\text { value }\end{array}$ \\
\hline The Openness of New Ideas Supporting Marketing Activities & 0.836 & 0.000 \\
\hline Continue in repairing product appearance & 0.688 & 0.000 \\
\hline Product Model Renewal & 0.715 & 0.000 \\
\hline Selling Management Renewal & 0.739 & 0.000 \\
\hline Management Renewal in Customer Relation & 0.802 & 0.000 \\
\hline \multicolumn{3}{|l|}{ Customers Responsiveness (CuR) } \\
\hline Ability in Fast-Responding Need on Changes on Product Design & 0.728 & 0.000 \\
\hline Ability in Fast-Responding Need on Changes on Product Motive & & 0.000 \\
\hline Variation & 0.779 & \\
\hline Ability in Fast-Responding Need on Changes on Raw Material & 0.783 & 0.000 \\
\hline Ability in Fast-Responding Need on Changes on Product Model & 0.791 & 0.000 \\
\hline Ability in Fast-Responding Need on Changes on Demand & 0.747 & 0.000 \\
\hline \multicolumn{3}{|l|}{ Competitor Responsiveness (CoR) } \\
\hline Ability in Fast-Responding Competitors' Product Design & 0.708 & 0.000 \\
\hline Ability in Fast-Responding Competitors' Selling Promotion & 0.710 & 0.000 \\
\hline Strategy & 0.653 & 0.000 \\
\hline $\begin{array}{l}\text { Ability in Fast-Responding Competitors' Change on Product } \\
\text { Motives }\end{array}$ & 0.712 & 0.000 \\
\hline Ability in Fast-Responding Competitors' Change on Product Models & & \\
\hline \multicolumn{3}{|l|}{ Religio-centric Positional Advantage (RPA) } \\
\hline Business Image Religiosity & 0.780 & 0.000 \\
\hline Aesthetic Design Religiosity & 0.754 & 0.000 \\
\hline Fashion Model Religiosity & 0.785 & 0.000 \\
\hline More Compliance on Religious Norms & 0.772 & 0.000 \\
\hline Marketing Communication Display Religiosity & 0.783 & 0.000 \\
\hline \multicolumn{3}{|l|}{ Marketing Performance (MP) } \\
\hline Sales Revenue Growth in the Last 3 Years & 0.775 & 0.000 \\
\hline Sales Volume Increase in the Last 3 Years & 0.718 & 0.000 \\
\hline Sales Target Achieved in the Last3 Years & 0.636 & 0.000 \\
\hline Total Customer Increase in the Last 3 Years & 0.708 & 0.000 \\
\hline
\end{tabular}

Source: Authors' own research results.

High construct reliability shows internal consistency, which means that indicators consistently represent the same latent construct (Hair et al., 2010). Construct reliability (CR) which is above 0.7 , variance extracted (VE) above 0.5 and discriminant validity (DV) above 0.7 are standards for measuring internal consistency of used indicators. Table 3 shows CR score which is higher than 0.7; VE which is higher than 0.5, DV which higher than the correlation among variables for MI, CuR, CoR, RPA and MR showed that each instruments had good validity in determining the used research variables.

The detection of multicollinearity symptoms on the regression model in this study can be seen in Table 3 . This study used 3 exogenous variables (independent variables) namely $\mathrm{MI}, \mathrm{CuR}$, CoR. The result of data analysis showed that the statistic coefficient of correlation between MI and CuR was 0.548, MI and CoR was 0.211, and $\mathrm{CuR}$ and CoR was 0.213. The scores were far smaller than 0.90 , and this leads us to the conclusion that the regression model constructed was free from serious mutlicollinearity symptoms (Ghozali, 2005). 
Table 3. Construct reliabilities, correlations and AVE

\begin{tabular}{|l|l|l|l|l|l|}
\hline $\mathbf{N}=\mathbf{3 3 5}$ & $\mathbf{1}$ & $\mathbf{2}$ & $\mathbf{3}$ & $\mathbf{4}$ & $\mathbf{5}$ \\
\hline 1. Marketing Innovation & $\mathbf{0 . 8 7 0}^{\boldsymbol{a}}$ & & & & \\
\hline 2. Responsive Capability on Customers & $\mathbf{0 . 5 4 8}^{\mathbf{b}}$ & $\mathbf{0 . 8 7 6}$ & & & \\
\hline 3. Responsive Capability on Competitors & $\mathbf{0 . 2 1 1}^{\mathbf{b}}$ & $\mathbf{0 . 2 1 3}$ & $\mathbf{0 . 7 8 6}$ & & \\
\hline 4. Religio-centric Positional Advantage & 0.630 & 0.513 & 0.287 & $\mathbf{0 . 8 8 3}$ & \\
\hline 5. Marketing Performance & 0.602 & 0.471 & 0.236 & 0.590 & $\mathbf{0 . 8 0 3}$ \\
\hline Discriminant Validity (DV) & 0.892 & 0.897 & 0.799 & 0.905 & 0.821 \\
\hline
\end{tabular}

a Factor reliabilities are on the diagonal (italic bold).

bCorrelation Coefficient of Exogenous Construct

Source: Authors' own research results.

\section{Results}

The test result of the full model of Structural Equation showed a strong Goodness-of-Fit index because it produced criteria in line with what SEM suggests. The insignificant score of $X^{2} 243.552$ on $\alpha 0.05$, GFI index 0.937, AGFI 0.920, TLI 0.941, the same score of CFI 0.948 or above 0.90 and other criteria such as RMSEA 0.018 which was lower than 0.08, CMIM/DF 1.107 which was lower than 2, and Hoetler 01 (373) score which was higher than the sample number(335) was in line with the criteria recommended in SEM (Table 2). This shows that the model recommended was fit or had feasibility to test the correlation among variables.

Table 4. Parameter estimates for the path: Direct effects

\begin{tabular}{|lll|l|c|c|c|c|}
\hline \multicolumn{2}{|c|}{ Regression } & & Std B & Unstd B & S.E. & C.R. & p-value \\
\hline $\mathrm{MI}$ & $\rightarrow$ & RPA & 0.480 & 0.482 & 0.080 & 6.623 & 0.000 \\
\hline $\mathrm{CuR}$ & $\rightarrow$ & RPA & 0.221 & 0.202 & 0.063 & 3.193 & 0.001 \\
\hline $\mathrm{CoR}$ & $\rightarrow$ & RPA & 0.139 & 0.804 & 0.352 & 2.282 & 0.022 \\
\hline $\mathrm{MI}$ & $\rightarrow$ & MP & 0.237 & 0.218 & 0.082 & 2.653 & 0.008 \\
\hline $\mathrm{CuR}$ & $\rightarrow$ & MP & 0.171 & 0.143 & 0.062 & 2.325 & 0.020 \\
\hline $\mathrm{CoR}$ & $\rightarrow$ & MP & 0.049 & 0.262 & 0.346 & 0.756 & 0.450 \\
\hline $\mathrm{RPA}$ & $\rightarrow$ & MP & 0.350 & 0.320 & 0.082 & 3.911 & 0.000 \\
\hline
\end{tabular}

Note: ${ }^{*} \mathrm{p}<0.05 ;{ }^{* * *} \mathrm{p}<0.01$

Source: Authors' own research results.

Table 4, shows that direct effect and positive significant effect of $M I$ on $R P A, C u R$ on $R P A, C o R$ on $R P A, M I$ on $M R, C u R$ on $M P$, and $R P A$ on $M P$. The test result on all correlations produced was significant on $\alpha 0.05$. This shows that $\mathrm{H} 1, \mathrm{H} 2, \mathrm{H} 3, \mathrm{H} 4, \mathrm{H} 5$, and H7 hypotheses were accepted. Related to H6, the direct effect of CoR on MP resulted in an insignificant coefficient on $\alpha 0.05$. Therefore, hypothesis $\mathrm{H} 6$ was rejected.

The procedure of mediated test proposed by Sobel (1982) was adopted to test the effect of mediation from RPA (Table 5). Along with H8, H9 and H10, the Sobel test of three antecedents really affected $M R$ through RPA. RPA took the role of a partial mediator in the correlation between MI and CuR with MR. The direct effect of $M I$ on $M R$ through $R P A$ was explained by the coefficient of Unstd $\beta 0.154(0.482 \times 0.320)$. The result of Sobel test showed the score of c.r 3.7067, SE 0.047 and $p$-value 0.001 so that it was significant on $\alpha 0.01$. The total effect of MI on MR through RPA was 0.372 $(0.218+0.154)$ which was higher than direct effect $(0.218)$ showing that RPA had an important role as a mediator in the correlation of MI with MR and became an important 
alternative in improving marketing performance. Therefore, this study accepted hypothesis $\mathrm{H} 8$.

Table 5. Parameter estimates for the path: Indirect effects (Sobel test)

\begin{tabular}{|lllll|c|c|c|l|}
\hline Path & & & & & Unstd B & S.E. & c.r. & P \\
\hline $\mathrm{MI}$ & $\rightarrow$ & $\mathrm{RPA}$ & $\rightarrow$ & MP & 0.154 & 0.047 & 3.275 & $0.001^{* *}$ \\
\hline $\mathrm{CuR}$ & $\rightarrow$ & $\mathrm{RPA}$ & $\rightarrow$ & MR & 0.065 & 0.026 & 2.477 & $0.013^{*}$ \\
\hline $\mathrm{CoR}$ & $\rightarrow$ & $\mathrm{RPA}$ & $\rightarrow$ & MR & 0.257 & 0.131 & 1.972 & $0.049^{*}$ \\
\hline
\end{tabular}

Note: ${ }^{*} \mathrm{p}<0.05 ;{ }^{* * *} \mathrm{p}<0.01$

Source: Authors' own research results.

Based on Sobel test on the correlation of $C u R$ and MR through RPA, the indirect effect of $C u R$ on MR through RPA was explained by the Unstd $\beta$ coefficient $0.065(0.202 \mathrm{x}$ 0.320 ). The result of Sobel test showed the score of c.r 2.477, SE 0.026 and $p$-value 0.013 so that it was significant on $\alpha 0.05$. The total effect of MI on MR through RPA was 0.236 $(0.171+0.065)$ which was higher than the direct effect $(0.171)$ showing that RPA had a very important role as a mediator in the correlation of $\mathrm{CuR}$ with $\mathrm{MR}$ and became an important alternative in improving marketing performance. Therefore, this study accepted hypothesis H9.

Based on the Sobel test on the correlation of CoR and MR through RPA, the indirect effect of $C o R$ on $M R$ through $R P A$ was explained by the Unstd $\beta$ coefficient 0.257 $(0.804 \times 0.320)$. The result of Sobel test showed the score of c.r 1.972 and $p$-value 0.049 so that it was significant on $\alpha 0.05$. The total effect of CoR on MR through RPA was 0.519 $(0.262+0.257)$ which was higher than the direct effect $(0.262)$ showing that RPA had a very important role as a mediator in the correlation of CoR with MR and became an important alternative in improving marketing performance. Therefore, this study accepted hypothesis H10.

\section{Discussions}

This study found an interesting complementary effect between MI, CuR and CoR on RPA and MP of small business. Specifically, this finding contributed significantly to extend the theory of RBV on the effect of complementary capability like what Sok et al. (2013) and Morgan (2012) have envisioned, a view that the ability of a business to develop and spread several internal capabilities (especially innovation capability and market response capability) are significant for sustainable growth. This finding highlighted that some small businesses could do more than the others on the market if they not only continuously developed and spread specific individual abilities, but they also had abilities which could complete one another. The latest studies concerning the role of complement capabilities in improving positional advantage and business performance are: Langerak et al. (2004) about market orientation, Nakata et al. (2006) about customer orientation, cross-function integration, new product team proficiency, Naidoo (2010) about marketing orientation, marketing innovation, Zhao et al. (2012) about marketing capability, market-linking capability and service design capability, and Ahmadi et al. (2013) about marketing resource and marketing capabilities, technology resource and technology capabilities. The current study extends the previous studies by examining the effect of complementary innovation capability, customer response capability, and competitor response capability on positional advantage and small businesses performance. 
The finding of this study showed that MI became an important driver for RPA and MP. An important relation of MI with RPA supported the finding of previous studies, such as Carbonell and Rodriguez (2006), and Naidoo (2010). While the important relation of MI with MP supported the findings of previous studies, such as Johnson et al. (2009), Hoonsopon and Ruenrom (2012), Sok et al. (2013), Rosli and Sidek (2013), and Karabulut (2015). The finding indicated that the improvement of market innovation at religion based market would improve religio-centric positional advantage and market performance. When market innovation is considered as a special ability to achieve positional advantage and business performance (Carbonell and Rodriguez, 2006; Naidoo, 2010), the innovation can be identified directly using the concept of innovation dynamic capabilities, where it is an exploration and path creation to develop a unique ability. An organization which develops dynamic innovation capabilities has the potential to save sustainable competitive advantage more than its competitors (Dixon et al., 2014). For example, in accordance with harmonizing a product with the market environment, a business needs to do creative innovative actions in the process of creating a new product. Starting from sensing within the market and finding information as much as possible about change of customer needs and competition intensity as well as chances which can be achieved, a business can design a new product in line with what the market needs (Lindblom et al., 2008). The ideas which come up from that learning process become a basis of innovation practices through a series of innovative activities such as a new way to connect with suppliers, structural organization change, organizational culture change, market strategy arrangement, employee development and other innovation activities which support the innovation of creating a new product.

This study supports the positive correlation proposed between customer response capability and market performance. It is in line with the previous studies which enrich the view on the role of customer orientation in improving business performance such as the views of: Narver and Slater (1990), Jaworski and Kohli (1993), Kohli et al. (1993), Appiah-Adu and Singh (1998), Brady and Cronin (2001), Cross et al. (2007), Rojas-Méndez and Rod (2013), etc. The idea comes as an improvement on market performance which may possibly be related to business responsive toward customer needs. A business becomes more responsive to improving customer relationship and service quality comprehensively. Customer responsiveness implies strategic orientation focused on customers. A more responsive business is reported to have bigger success than its competitors in improving service advantage and customer satisfaction (Daugherty et al., 1995). The ability becomes a prerequisite needed to support a long-term relationship between buyers and sellers who are now closer. On several levels, customer response capability is built by improving the abilities to respond to needs relating to: product design, product motive, product raw material, product model and high responsiveness for customer request. Generally, the positive relationship between customer response capability and marketing performance extends our understanding about the relationship between market orientation and performance as studied by Narver and Slater (1990) and Jaworski and Kohli (1993). Besides, this article provides a theoretical contribution by presenting a new model which integrates the important contextual mediator of religio-centric positional advantage in the correlation of customer response capability and business performance. Specifically, the findings of this study establish the role of mediation of religio-centric positional advantage in determining the correlation of customer response capability and small business performance in specific religion-based industries. 
Another finding shows there was a positive correlation of CoR and RPA, but not MP. This result is in line with previous studies on the role of cultural orientation competitors in enhancing positional advantage, conducted by Narver and Slater (1990), Jaworski and Kohli (1993), Kohli et al. (1993), Appiah-Adu and Singh (1998), Brady and Cronin (2001), Cross et al. (2007), Rojas-Méndez and Rod (2013). This can be done such as by actively collecting information on product designs, product models and competitors' sales promotion; improving abilities to modify products to be equal or better than the competitors', abilities to differentiate products with different designs from the competitors', and abilities to establish cooperation with other business, to adjust sales promotion management with on-going competition patterns.

The study found that marketing performance did not depend on the competitors' response capability. This indicates that in a religion-based market segment, even though the businesses' ability to respond to competitors' strategies is higher, this does not always produce a better marketing performance. It will be difficult for a small business to cope with competition which is based only on the ability to react to competitors' strategies. In addition, in a religion-based market, a very close relationship between companies, especially in retail markets, enables them to lower the competition tension by cooperation in the commodity procurement. This finding is contrary to the common view that competitors' orientation, in principle, is always associated with positive performance (Narver and Slater, 1990; Kennedy et al., 2003; Sørensen, 2009). Instead, this finding supports that the opposite view competitor orientation is not a predictor of business performance, such as Mueller and Gemünden (2009) and Lengler et al. (2013).

The present research has also shown how important the role of RPA is for businesses engaged in very dynamic religion-based fashion industries and that it has the characteristics of short life cycles, unstable demand, low predictability and the high impulse purchasing level (Christopher et al., 2004). RPA has been a convincing mediator in the correlation of MI, CuR and CoR to MP. Our findings have confirmed the role of internal factors in strengthening the RPA, as the RPA internal driver; MI, CUR and CoR appear when a business has innovation culture and strong market orientation culture as well. Strong innovation culture enables all the business's components to work hard, finding new ideas which stimulate business progress, trying new ways which are beneficial to business advancement, continuous improvement on the products' appearance, and constantly renewing offered product models. Whereas, a market orientation culture allows all the company's components to strive improving their capabilities to respond to the changes on customer needs and to react quickly and appropriately to competitors' strategy changes. In Islamic fashion industry, the ability to give quick and appropriate responses to changes of design, motive, model and raw material needs is most essential to maintain a positional advantage and MP progress.

But for the insignificant correlation between CoR and MP, the correlations between MI and CuR with MP were found sufficient. However, we also examined alternative models, namely by proposing a positional religio-centric advantage as a variable which mediated the correlation of $\mathrm{MI}, \mathrm{CuR}$ and $\mathrm{CoR}$ with marketing performance. Simple lines analysis was set to determine the total effect of the correlations between the variables studied. The findings show that total effect of the partial indirect correlations between MI, CuR and CoR with the MP shows a larger value than direct connection. This proves that RPA really mediates the correlations of MI, CuR and CoR with MP. However, the MI's total effect is the largest of all considered independent variables, pointing out that religio-centric positional advantage is an important supporter of marketing performance, but the more important thing is the 
ability of the company to constantly improve marketing innovativeness. These findings lead us to the view of more complex correlations of hypothesized variables, which is, in addition to a direct correlation of MI, CuR and CoR with marketing performance, and the correlations may also be indirect through the religio-centric positional advantage.

\section{Conclusions}

This study is aimed at investigating the correlation of MI, CuR and CoR with RPA and $\mathrm{MR}$, as well as the RPA mediating role in the correlation of these five variables. A model correlation of MI, CuR and CoR with RPA and MP is built and tested empirically using structural equation model. Three key findings are described as follows: (1) the small companies in these religion-based market segments are likely to have better marketing performance if they have religio-centric positional advantage, (2) that increased marketing innovativeness, customers' response capabilities and competitors' response capabilities are required to develop and maintain positional religio-centric advantage, and (3) thus religio-centric positional advantage indeed plays a role as a mediator in the correlation between marketing innovativeness, customers' responsiveness and competitors' responsiveness and marketing performance.

Theoretically, the findings of this study contribute to solving problems of inconsistent correlation of marketing innovativeness and market responsiveness with marketing performance. The new concept of religio-centric positional advantage which is offered as mediation in connection with marketing innovativeness and marketing performance has been tested and actually plays an important role in bridging the correlations between the two variables. This study contributes mainly to the internalization of religious values in the study of business positional advantage associated with marketing innovativeness, customers' response capabilities, competitors' response capabilities and marketing performance which was still ignored by previous researchers. This research has found that in the studied religion-based market, the businesses' success largely depends on how far the company gains a religiocentric positional advantage.

Businesses with strong religio-centric positional advantage will have a better chance in getting a superior marketing performance. In addition, this study has found that marketing innovativeness, customers' response capabilities and competitors' response capabilities are the key factors in deciding the religio-centric positional advantage. Thus, this study has found a very big role of religio-centric positional advantage in mediating marketing innovativeness, customers' response capabilities and competitors' response capabilities with marketing performance, and moreover it has contributed to the development of science, especially to the Resource Based View (RBV) theoretical background, Resource Advantage Theory (RA Theory) and Marketing Management.

\section{Limitations and directions for future studies}

This study has limitations that must be recognized and need to be addressed. First, the target population of this study is represented by small businesses of Muslim clothing with Islamic religious background in Indonesia, so the generalizability of this study is limited. Differences in religious backgrounds and business scales between micro, small, medium and large scales may lead to differences in the businessperson's behavioral characteristics of these three groups. The study replicating the model of religio-centric positional advantage can be done by involving entire companies in religion-based 
market segments with different religion background, either in micro, small, medium and big companies, in a broader scope, either nationally or internationally. Second, this research model is built only by placing three antecedent variables of religio-centric positional advantage determinant, namely MI, CuR and CoR. Future studies may extend their scope to examine the correlation among various dimensions of marketing innovativeness (such as product innovativeness, processes innovativeness, and customer relationships innovativeness) with religio-centric positional advantage and marketing performance. It is very possible for future studies to involve the moderating effects that affect the causal correlation which is not hypothesized in this study, for example, combining the role of contingency factors as moderating market environment that affect the relationship between marketing innovativeness, customers' response capabilities and competitors' response capabilities with religio-centric positional advantage and marketing performance. Market environmental variables such as the Ulama's fatwa, company size, religiosity, and customers' tastes can also be used as an extension of the existing models, so the studies on this topic may be developed better. Third, although this study has contributed to the research field and management practices to improve SMEs' marketing performance, it is designed by quantitative analysis with cross-sectional data, and, it therefore need qualitative research to gain a more complete understanding of how companies develop and manage all religio-centric positional advantages in religious-based market segments. In addition, the crosssectional study design in this study may not fully capture the dynamic correlation between marketing innovativeness, customers' response capabilities and competitors' response capabilities and religio-centric positional advantage and SMEs' marketing performance. Further studies can utilize a combination of time series data and crosssection to gain a better understanding of the patterns, determinants and dynamic of changes between the studied constructs.

\section{References}

Abou-Moghli, A.A., Abdallah, G.M.A. and Muala, A.A. (2012), "Impact of innovation on realizing competitive advantage in banking sector in Jordan", American Academic \& Scholarly Research Journal, Vol. 4, No. 5.

Abu-Nimer, M. (2004), "Religion, dialogue, and non-violent actions in Palestinian-Israeli conflict", International Journal of Politics, Culture and Society, Vol. 17, No. 3, pp. 491-511.

Adis, A.A.A. and Jublee, E. (2010), "Market orientation and new product performance: The mediating role of product advantage", African Journal of Marketing Management, Vol. 2, No. 5, pp. 91-100.

Ahmadi, H., O'Cass, A. and Miles, M.P. (2013). "Product resource-capability complementarity, integration mechanisms, and first product advantage", Journal of Business Research, Vol. 67, No. 5, pp. 1-6.

Al-Saed, R.R.P. and Upadhya, A. (2010), "Entrepreneurial orientation, knowledge process, and marketing performance: An investigation in small organizations in Sharjah Emirate", Journal of Asia Entrepreneurship and Sustainability, Vol. 6, No. 2, pp. 103-120.

Al-Zyadaat, M.A., Saudi, M.A. and Al-Awamreh, M.A. (2012), "The relationship between innovation and marketing performance in business organizations: An empirical study on industrial organizations in the industrial city of King Abdullah II", International Business and Management, Vol. 5, No. 2, pp. 76-84. 
Alpay, G., Bodur, M., Yilmaz, C. and Buyukbalci, P. (2012), "How does innovativeness yield superior firm performance? The role of marketing effectiveness", Innovation: Management, policy \& practice, Vol. 14, No. 1, pp. 107-128.

Appiah-Adu, K. and Singh, S. (1998), "Customer orientation and performance: a study of SMEs", Management Decision, Vol. 36, No. 6. pp. 385-394.

Ar, I.M. and Baki, B. (2011), "Antecedents and performance impacts of product versus process innovation. Empirical evidence from SMEs located in Turkish science and technology parks", European Journal of Innovation Management, Vol. 14, No. 2, pp. 172-206.

Atalaya, M., Anafarta, N. and Sarvanc, F. (2013), "The relationship between innovation and firm performance: An empirical evidence from Turkish automotive supplier industry", Procedia - Social and Behavioral Sciences, Vol. 75, 3 April 2013, pp. 226235.

Barnes, L., Hayes, S.G. and Jones, N. (2006), "Fast fashion: a financial snapshot", Journal of Fashion Marketing and Management: An International Journal, Vol. 10, No. 3, pp. 282-300.

Barnes, L. and Lea-Greenwood, G. (2006), "Fast fashioning the supply chain: shaping the research agenda", Journal of Fashion Marketing and Management: An International Journal, Vol. 10, No. 3, pp. 259-271.

Barnes, L. and Lea-Greenwood, G. (2010), "Fast fashion in the retail store environment", International Journal of Retail \& Distribution Management, Vol. 38, No. 10, pp. 760-772.

Bodlaj, M. (2010), "The impact of a responsive and proactive market orientation on innovation and business performance", Economic and Business Review, Vol. 12, No. 4, pp. 241-261.

Brady, M.K. and Cronin, J.J. (2001), "Customer orientation: Effects on customer service perceptions and outcome behaviors", Journal of Service Research, Vol. 3, No. 3, pp. 241-251.

Brïdson, K. and Evans, J. (2004), "The secret to a fashion advantage is brand orientation", International Journal of Retail \& Distribution Management, Vol. 32, No. 8, pp. 403411.

Bridson, K., Evans, J., Mavondo, F. and Minkiewicz, J. (2013), "Retail brand orientation, positional advantage and organisational performance", The International Review of Retail, Distribution and Consumer Research, Vol. 23, No. 3, pp. 245-264.

Carbonell, P. and Escudero, A.I.R.G. (2010), "The effect of market orientation on innovation speed and new product performance", Journal of Business \& Industrial Marketing, Vol. 25, No. 7, pp. 501-513.

Carbonell, P. and Rodriguez, A.I. (2006), "The impact of market characteristics and innovation speed on perceptions of positional advantage and new product performance", International Journal of Research in Marketing, Vol. 23, No. 1, pp. 112.

Cascio, R.P. (2011), "Marketing innovation and firm performance: Research model, research hypotheses, and managerial implication", PhD Thesis, University of Central Florida Orlando, Florida.

Chao, M.C.-H. and Spillan, J.E. (2010), "The journey from market orientation to firm performance: A comparative study of US and Taiwanese SMEs", Management Research Review, Vol. 33, No. 5. pp. 472-483.

Chavosha, A., Halimi, A.B., Soheilirad, S., Ghajarzadeh, A. and Nourizadehe, A. (2011), "Customer responsiveness and export performance of selected electronic 
equipment export companies in Malaysia", International Conference on Social Science and Humanity, Vol. 5, pp. 124-127.

Christopher, M., Lowson, R. and Peck, H. (2004), "Creating agile supply chains in the fashion industry", International Journal of Retail \& Distribution Management, Vol. 32, No. 8, pp. 367-376.

Chung, H.F.L. (2012), "Export market orientation, managerial ties, and performance", International Marketing Review, Vol. 29, No. 4, pp. 403-423.

Cooper, R.G. and Kleinschmidt, E.J. (2000), "New product performance: What distinguishes the star products", Australian Journal of Management, Vol. 25, No. 1, pp. 17-45.

Corneo, G. and Jeanne, O. (1999), "Segmented communication and fashionable behavior", Journal of Economic Behavior \& Organization, Vol. 39, No. 4, pp. 371-385.

Cross, M.E., Brashear, T.G., Rigdon, E.E. and Bellenger, D.N. (2007), "Customer orientation and salesperson performance", European Journal of Marketing, Vol. 41, No. 7-8, pp. 821-835.

Daugherty, P.J., Ellinger, A.E. and Rogers, D.S. (1995), "Information accessibility: Customer responsiveness and enhanced performance", International Journal of Physical Distribution \& Logistics Management, Vol. 25, No. 1, pp. 4-17.

Day, G.S. (1994), "The capabilities of market-driven organizations", Journal of Marketing, Vol. 58, No. 4, pp. 37-52.

Dibrell, C., Craig, J.B. and Neubaum, D.O. (2013), "Linking the formal strategic planning process, planning flexibility, and innovativeness to firm performance", Journal of Business Research, Vol. 67, No. 9, pp. 2000-2007.

Dixon, S., Meyer, K. and Day, M. (2014), "Building dynamic capabilities of adaptation and innovation: A study of micro-foundations in a transition economy", Long Range Planning, Vol. 47, No. 4, pp. 186-205.

Dong, X., Hinsch, C.A., Zou, S. and Fu, H. (2013), "The effect of market orientation dimensions on multinational SBU's strategic performance", International Marketing Review, Vol. 30, No. 6, pp. 591-616.

Forney, J.C., Park, E.J. and Brandon, L. (2005), "Effects of evaluative criteria on fashion brand extension", Journal of Fashion Marketing and Management: An International Journal, Vol. 9, No. 2, pp. 156-165.

Fuentes, J.B. and Quiroga, E. (2009), "The 'fashion-form' of modern society and its relationship to psychology", The Spanish Journal of Psychology, Vol. 12, No. 1, pp. 383-390.

Gao, Y. (2010), "Measuring marketing performance: a review and a framework", The Marketing Review, Vol. 10, No. 1, pp. 25-40.

Ghozali, I. (2005), Aplikasi analisis multivariate dengan program SPSS, Badan Penerbit Universitas Diponegoro.

Gökariksel, B. and McLarney, E. (2010), "Muslim women, consumer capitalism, and the Islamic culture industry", Journal of Middle East Women's Studies, Vol. 6, No. 3, pp. 1-18.

Hair, J.F., Black, W.C., Babin, B.J. and Anderson, R.E. (2010), Multivariate data analysis, $7^{\text {th }}$ Ed., Prentice Hall, New York.

Hanzaee, K.H. and Chitsaz, S. (2011), "A review of influencing factors and constructs on the Iranian women's Islamic fashion market", Interdisciplinary Journal of Research in Business, Vol. 1, No. 4, pp. 94-100. 
Healy, B., Ledwith, A. and O’Dwyer, M. (2014), "Perceptions of product advantage, NPD and organisational performance", Journal of Small Business and Enterprise Development, Vol. 21, No. 1, pp. 49-69.

Herche, J. (1994), "Ethnocentric tendencies, marketing strategy and import purchase behaviour", International Marketing Review, Vol. 11, No. 3, pp. 4-16.

Hitt, M.A., Ireland, R.D. and Hoskisson, R.E. (2001), Strategic management: Competitiveness and globalization, $4^{\text {th }}$ Ed., South-Western College Publishing.

Hoonsopon, D. and Ruenrom, G. (2012), "The impact of organizational capabilities on the development of radical and incremental product innovation and product innovation performance", Journal of Managerial Issues, Vol. 24, No. 3, pp. 250276.

Hsieh, M.-H., Tsai, K.-H. and Wang, J.-R. (2008), "The moderating effects of market orientation and launch proficiency on the product advantage-performance relationship", Industrial Marketing Management, Vol. 37, No. 5, pp. 580-592.

Huang, C.-T. and Tsai, K.-H. (2014), "Synergy, environmental context, and new product performance: A review based on manufacturing firms", Industrial Marketing Management, Vol. 43, No. 8, pp. 1407-1419.

Hunt, S.D. and Morgan, R.M. (1995), "The comparative advantage theory of competition", Journal of Marketing, Vol. 59, No. 2, pp. 1-15.

Irsic, M. (2014), "The impact of relationship orientation on positional advantage of the companies in Slovenia and the role of relationship value", Journal of Strategic and International Studies, Vol. 9, No. 6, pp. 27-33.

Jaworski, B., Kohli, A.K., and Sahay, A. (2000), "Market-driven versus driving markets", Academy of Marketing Science, Vol. 28, No. 1, pp. 45-54.

Jaworski, B.J. and Kohli, A.K. (1993), "Market orientation: Antecedents and consequences", Journal of Marketing, Vol. 57, pp. 53-70.

Jiménez-Guerrero, J.F., Gázquez-Abad, J.C. and Linares-Agüera, E.d.C. (2014), "Using standard CETSCALE and other adapted versions of the scale for measuring consumers' ethnocentric tendencies: An analysis of dimensionality", $B R Q$ Business Research Quarterly, Vol. 17, No. 3, pp. 174-190.

Johnson, A.J., Dibrell, C.C. and Hansen, E. (2009), "Market orientation, innovativeness, and performance of food companies", Journal of Agribusiness, Vol. 27, No. 1-2, pp. 85-106.

Junge, M., Severgnini, B. and Sørensen, A. (2015), "Product-marketing innovation, skills, and firm productivity growth", Review of Income and Wealth, Vol. 62, No. 4, pp. 724-757.

Karabulut, A.T. (2015), "Effects of innovation types on performance of manufacturing firms in Turkey", Procedia - Social and Behavioral Sciences, Vol. 195, 3 July 2015, pp. 1355-1364.

Kaynak, R. and Eksi, S. (2011), "Ethnocentrism, religiosity, environmental and health consciousness: Motivators for anti-Consumers", Eurasian Journal of Business and Economics, Vol. 4, No. 8, pp. 31-50.

Kennedy, K.N., Goolsby, J.R. and Arnould, E.J. (2003), "Implementing a customer orientation: Extension of theory and application", Journal of Marketing, Vol. 67, No. 4, pp. 67-81.

Kim, W.C. and Mauborgne, R. (1997), "Value innovation: The strategic logic of high growth", Harvard Business Review, Vol. 75, No. 1, pp. 102-12.

Kohli, A.K., Jaworski, B.J. and Kumar, A. (1993), "MARKOR: A measure of market orientation", Journal of Marketing Research, Vol. 30, No. 4, pp. 467-477. 
Kotler, P. and Armstrong, G., Wong, V. (2000), Principles of marketing, 9 ${ }^{\text {th }}$ Ed., Prentice Hall.

Langerak, F., Hultink, E.J. and Robben, H.S.J. (2004), "The impact of market orientation, product advantage, and launch proficiency on new product performance and organizational performance", Journal of Product Innovation Maagement, Vol. 21, No. 2, pp. 79-94.

Ledwith, A. and O'Dwyer, M. (2008), "Product launch, product advantage and market orientation in SMEs", Journal of Small Business and Enterprice Development, Vol. 15, No. 1, pp. 96-110.

Lee, W.J., Phau, I. and Roy, R. (2013), "“Bonds” or “Calvin Klein” Down-under: Consumer ethnocentric and brand country origin effects towards men's underwear", Journal of Fashion Marketing and Management: An International Journal, Vol. 17, No. 1, pp. 65-84.

Lengler, J.F., Sousa, C.M.P. and Marques, C. (2013), "Exploring the linear and quadratic effects of customer and competitor orientation on export performance", International Marketing Review, Vol. 30, No. 5, pp. 440-468.

Lewrick, M., Omar, M. and Williams, L.R.Jr. (2011), "Market Orientation and Innovators' Success: An Exploration of the Influence of Customer and Competitor Orientation", Journal of Technology Management \& Innovation. Vol. 6, No. 3, pp. 48-62.

Li, J.J. and Zhou, K.Z. (2010), "How foreign firms achieve competitive advantage in the Chinese emerging economy: Managerial ties and market orientation", Journal of Business Research, Vol. 63, No. 8, pp. 856-862.

Lindblom, A.T., Olkkonen, R.M., Mitronen, L. and Kajal, S. (2008), "Market-Sensing Capability and Business Performance of Retail Entrepreneurs", Contemporary Management Research, Vol. 4, No. 3, pp. 219-236.

Lumpkin, G.T. and Dess, G.G. (1996), "Clarifying the entrepreneurial orientation construct and linking it to performance", Academy of Management Review, Vol. 21, No. 1, pp. 135-172.

Matanda, M.J. and Ndubisi, N.O. (2009), "Market orientation, supplier perceived value and business performance of SMEs in a Sub-Saharan African nation", Journal of Enterprise Information Management, Vol. 22, No. 4, pp. 384-407.

Matear, S., Gray, B.J. and Garrett, T. (2004), "Market orientation, brand investment, new service development, market position and performance for service organisations", International Journal of Service Industry Management, Vol. 15, No. 3, pp. 284-301.

Merrilees, B., Rundle-Thiele, S. and Lye, A. (2011), "Marketing capabilities: Antecedents and implications for B2B SME performance", Industrial Marketing Management, Vol. 40, No. 3, pp. 368-375.

Milles, R.E., Snow, C.C., Meyer, A.D. and Coleman, H.J. (1978), "Organizational Strategy, Structure and Process", The Academy of Management Review, Vol. 3, No. 3, pp. 546-562.

Moreira, J., Silva, M.J., Simões, J. and Sousa, G. (2012), "Drivers of marketing innovation in Portuguese firms", Amfiteatru Economic, Vol. 14, No. 31, pp. 195-206.

Morgan, N.A. (2012), "Marketing and business performance", Journal of the Academy of Marketing Science, Vol. 40, No. 1, pp. 102-119.

Mueller, T.A. and Gemünden, H.G. (2009), "Founder team interaction, customer and competitor orientation in software ventures", Management Research News, Vol. 32, No. 4, pp. 539-554. 
Naidoo, V. (2010), "Firm survival through a crisis: The influence of market orientation, marketing innovation and business strategy", Industrial Marketing Management, Vol. 39, No. 1, pp. 1311-1320.

Nakata, C., Im, S., Park, H. and Ha, Y.-W. (2006), "Antecedents and consequence of Korean and Japanese new product advantage", Journal of Business Research, Vol. 59, No. 1, pp. 28-36.

Narver, J.C. and Slater, S.F. (1990), "The Effect of a Market Orientation on Business Profitability", Journal of Marketing, Vol. 54, No. 4, pp. 20-35.

Nwokah, N.G. (2009), "Customer-focus, competitor-focus and marketing performance", Measuring Business Excellence, Vol. 13, No. 3, pp. 20-28.

O'Dwyer, M. and Ledwith, A. (2009), "Determinants of new product performance in small firm", International Journal of Entrepreneurial Behaviour \& Research, Vol. 15, No. 2, pp. 124-136.

Pehrsson, A. (2014), "Firms' customer responsiveness and performance: the moderating roles of dyadic competition and firm's age", Journal of Business \& Industrial Marketing, Vol. 29, No. 1, pp. 34-44.

Prasertsang, S. and Ussahawanitchakit, P. (2011), "Corporate social responsibility strategy, marketing performance and marketing sustainability: an empirical investigation of ISO 14000 businesses in Thailand", International Journal of Business Strategy, Vol. 11, No. 3, pp. 58-77.

Ray, J.J. and Doratis, D. (1972), "Religiocentrism \& Ethnocentrism: Catholic and Protestant in Australian Schools", Sociological Analysis, Vol. 32, No. 3, pp. 170179.

Rojas-Me'ndez, J.I. and Rod, M. (2013), "Chilean wine producer market orientation: comparing MKTOR versus MARKOR", International Journal of Wine Business Research, Vol. 25, No. 1, pp. 27-49.

Rosli, M.M. and Sidek, S. (2013), "The Impact of Innovation on the Performance of Small and Medium Manufacturing Enterprises: Evidence from Malaysia", Journal of Innovation Management in Small \& Medium Enterprise, Vol. 2013 No. 2013, pp. 116.

Roy, S. and Goswami, P. (2007), "Structural equation modeling of value-psychographic trait-clothing purchase behavior: a study on the urban college-goers of India", Young Consumers, Vol. 8, No. 4, pp. 269-277.

Saida, M., Hassan, F., Musa, R. and Rahman, N.A. (2014), "Assessing consumers' Perception, knowledge and religiosity on Malaysia's halal food products", Procedia - Social and Behavioral Sciences, Vol. 130, No. 1, pp. 120-128.

Shergill, G.S. and Nargundkar, R. (2005), "Market Orientation, Marketing Innovation as Performance Drivers", Journal of Global Marketing, Vol. 19, No. 1 pp. 27-47.

Sok, P., O'Cass, A. and Sok, K.M. (2013), "Achieving superior SME performance: Overarching role of marketing, innovation, and learning capabilities", Australasian Marketing Journal, Vol. 21, no. 1, pp. 161-167.

Soliman, H.S. (2011), "Customer relationship management and its relationship to the marketing performance", International Journal of Business and Social Science, Vol. 2, No. 10, pp. 166-182.

Sørensen, H.E. (2009), "Why competitors matter for market orientation", European Journal of Marketing, Vol. 43, No. 5/6, pp. 735-761.

Srivastava, R.K., Fahey, L. and Christensen, H.K. (2001) "The resource-based view and marketing: The role of market- based assets in gaining competitive advantage.". Journal of Management, Vol. 27, No. 6, pp. 777-802. 
Srivastava, R.K., Shervani, T.A. and Fahey, L. (1999), "Marketing, Business Processes, and Shareholder Value: An Organizationally Embedded View of Marketing Activities and the Discipline of Marketing", Journal of Marketing, Vol. 63, Special Issue, pp. 168-179.

Sterkens, C. and Anthony, F.-V. (2008), "A Comparative Study of Religiocentrism among Christian, Muslim and Hindu Students in Tamil Nadu, India", Journal of Empirical Theology, Vol. 21, No. 1, pp. 32-67.

Tsai, K.-H. and Hsu, T.T. (2013), "Cross-Functional collaboration, competitive intensity, knowledge integration mechanisms, and new product performance: A mediated moderation model", Industrial Marketing Management. Vol. 43, No. 2, pp. 293303.

Wang, C.L. and Ahmed, P.K. (2007), "Dynamic capabilities: a review and research agenda", International Journal of Management Reviews, Vol. 9, No. 1, pp. 31-51.

Wong, S.K.S. (2012), "The influences of entrepreneurial orientation on product advantage and new product success", Journal of Chinese Entrepreneurship, Vol. 4, No. 3, pp. 243-262.

Yalcinkaya, G., Calantone, R.J. and Griffith, D.A. (2007), "An Examination of Exploration and Exploitation Capabilities: Implications for Product Innovation and Market Performance", Journal of International Marketing. Vol. 15, No. 4, pp. 63-93.

Yang, L.-R., Chen, J.-H. and Wang, X.-L. (2014), "Assessing the effect of requirement definition and management on performance outcomes: Role of interpersonal conflict, product advantage and project type", International Journal of Project Management, Vol. 33, No. 1, pp. 67-80.

Zhao, Y.L., Song, M. and Storm, G.L. (2012), "Founding Team Capabilities and New Venture Performance: The Mediating Role of Strategic Positional Advantages", Entrepreneurship Theory \& Practice, Vol. 37, No. 4, pp. 789-814.

Zhou, K.Z., Brown, J.R. and Dev, C.S. (2009), "Market orientation, competitive advantage, and performance: A demand-based perspective", Journal of Business Research, Vol. 62, No. 11, pp. 1063-1070. 